University of Nebraska - Lincoln

DigitalCommons@University of Nebraska - Lincoln

Faculty Publications: Department of Teaching, Department of Teaching, Learning and Teacher Learning and Teacher Education

Education

2014

Narrative understandings of a school policy: Intersecting student, teacher, parent and administrator perspectives

Elaine Chan

Vicki Ross

Follow this and additional works at: https://digitalcommons.unl.edu/teachlearnfacpub

Part of the Curriculum and Instruction Commons, and the Teacher Education and Professional

Development Commons

This Article is brought to you for free and open access by the Department of Teaching, Learning and Teacher Education at DigitalCommons@University of Nebraska - Lincoln. It has been accepted for inclusion in Faculty Publications: Department of Teaching, Learning and Teacher Education by an authorized administrator of DigitalCommons@University of Nebraska - Lincoln. 


\title{
Narrative understandings of a school policy: Intersecting student, teacher, parent and administrator perspectives
}

\author{
Elaine Chan and Vicki Ross
}

Elaine Chan is an associate professor in the Department of Teaching, Learning and Teacher Education, College of Education and Human Sciences, University of Nebraska- Lincoln, 24 Henzlik Hall, Lincoln, NE 68588-0355, USA; email echan2@unl.edu. Her teaching and research interests are focused on diversity, curriculum and narrative inquiry. She is co-editor of 'Narrative Inquirers in the Midst of Meaning-Making: Interpretive Acts of Teacher Educators.'

Vicki Ross is an associate professor in the Department of Teaching and Learning, College of Education, Northern Arizona University, P.O. Box 5774, Flagstaff, AZ 86011- 5774, USA; email vicki.ross@nau. edu. Her research and teaching interests are in the areas of mathematics education, teacher development, narrative inquiry and curriculum. She is co-editor of Narrative Inquirers in the Midst of Meaning-Making: Interpretive Acts of Teacher Educators, (Emerald, 2012).

\begin{abstract}
In this article, we examine one school's experience with policy, as a means of shedding light on the intersection of factors contributing to challenges of implementing policies to support the academic achievement and social adaptation of immigrant and minority students in their school context. We begin with the presentation of a 'big fight' between two students of different ethnic and racial backgrounds, and consider multiple perspectives of how the disagreement was addressed by teachers and administrators, to offer insight into how issues of race and policy might have been understood by members of the school community. We use a narrative inquiry approach to examine ways in which a policy designed to enhance student participation was interpreted by various members of this school community. This study reveals nuances of the intersection between culture and (hidden) curriculum as it relates to the implementation of policies aimed at creating and maintaining safe school communities.
\end{abstract}

Keywords: curriculum, minority group students, teacher knowledge, multicultural education, school policies and practices, narrative inquiry

Published in Journal of Curriculum Studies 46:5 (2014), pp 656-675.

doi 10.1080/00220272.2014.911352

Copyright (c) 2014 Taylor \& Francis. Used by permission. 


\section{Introduction}

To a greater or lesser degree, countries around the world experience racial tensions. Governments, public institutions and schools establish policies for how these issues are handled. Addressing the needs of an increasingly diverse population (Statistics Canada, 2007a, 2007b, 2008; U.S. Census Bureau, 2010) is among the most significant current educational challenges facing North American schools. The importance of teachers, administrators and parents working to develop and implement appropriate curriculum, policies and practices to support students of diverse backgrounds has been identified as being critical to their academic achievement and, indeed, social adaptation. And, while this work originates in Toronto, Canada, understanding of the tensions associated with working with diverse school communities presented and examined in this study could be applied to diverse urban school communities worldwide.

Understanding the challenges students may encounter as they adapt to school communities in a new country may inform teachers of the kinds of social support students need as they become accustomed to their new schools and classrooms (Pipher 2002; Ross \& Chan, 2008). While the existing research offers glimpses of the kinds of initiatives school communities have implemented, knowledge about the extent to which respective practices and policies have succeeded in support-

ing the academic achievement and social adaptation of immigrant and minority students remains emergent. Not only is further knowledge about the kinds of policies and practices in place in schools needed, but knowledge about ways in which these practices and policies are experienced by students, teachers, and others in their schools is also just developing. Difficulties in identifying successful practices and policies may be attributed, at least in part, to the lack of awareness about the multifaceted nature of immigrant and minority student needs and the extent to which their needs may be so vastly different than what we had expected or assumed. To this end, we share this story:

\section{Sixth-grade sweethearts}

What happened was that there was a fight in the playground. A child who was the perpetrator's girlfriend the year before 
got bopped in the nose by the boyfriend. They were girlfriend and boyfriend in Grade 6 and who knows what happened. I don't know exactly what caused the fight, however, the perpetrator was egged on, and he bopped her in the nose. She had a bloody nose. She came in. A school administrator phoned her parents, her parents phoned the police and phoned an ambulance. (Fieldnotes, April 2002) ${ }^{1}$

We begin with the story of an altercation between two seventh grade students that escalated to involve many other members of the school community. This account of the disagreement, told to us by a schoolparent relations officer who was based at Bay Street School, in Toronto, Ontario, Canada, is presented to provide a context for the ensuing discussion.

\section{Framing the story: making sense of Umar's story}

We employ a narrative inquiry approach to examine one school's experience with policy, as a means of shedding light on the intersection of factors contributing to challenges of implementing policies to support the academic achievement and social adaptation of immigrant and minority students in their school context. Hamann and Rosen (2011) described their work as an illustration of the contribution of an anthropological perspective to the domain of educational policy implementation, recognizing that anthropological renderings of educational policy implementation may account for what Maxwell (1992) characterized as the 'validity of qualitative data' (p. 473). We suggest that a comparable argument may be made about the validity of narrative accounts of policy implementation, as told through the 'stories of experience' (Connelly \& Clandinin, 1988) of members of the school community featured in this study. Our intention is to illustrate complexities of the implementation of school policies using narrative inquiry. We highlight nuances of policy implementation revealed when

1. While we have introduced this story to explore complexities of meeting the curricular needs of a diverse student population in a previous piece (Chan \& Ross, 2009), we focus here on ways in which this same situation could be examined to highlight challenges of policy implementation. 
researchers look beneath the surface to examine interactions among members of a school community, particularly when there is disagreement about ways in which a policy is interpreted and implemented within the school.

\section{Researchers in the school}

Drawing upon narrative inquiry methodology (Clandinin \& Connelly, 1994, 2000), we examine the experiences of a middle school student caught up in the implementation of a policy designed to keep students safe at school. We describe ways in which the policy was interpreted by various members of his school community.

For several years, we engaged in a narrative inquiry to explore teachers', administrators', parents' and students' 'stories of experience' (Connelly \& Clandinin, 1988) of an educational equity policy in their school. We began observations as school-based researchers, and interacted with members of the school community in the context of classroom and school activities. We participated in regular classroom lessons and activities as participant observers, attended staff meetings (Ministry of Education and Training, 2004a, 2004b), School Council meetings, field trips and school events such as band concerts, curriculum nights and school celebrations to learn about ways in which issues of ethnicity, culture and curriculum were experienced by members of the school community. We also conducted research interviews, and collected school board policy documents, curriculum documents, samples of student work, communication between home and school, community announcements and media coverage to learn about the experiences of students, teachers, parents and administrators in the school.

We recorded extensive fieldnotes following school visits, classroom observations and interviews and conversations with members of the school community. We drew upon student, teacher and parent responses to school practices and policies as the foundation for our 'stories of experience' (Connelly \& Clandinin, 1988). These stories illustrate challenges arising in conflicting experiences of policy implementation.

Employing a storying and restorying process to acknowledge teacher, administrator, parent and student responses to a schoolyard fight, we explore how varying perceptions or interpretations of a school board policy inform a nuanced understanding of complexities 
individuals may encounter in the implementation of practices and policies designed to support a diverse student population. These stories provide a starting point for discussion about unexpected consequences of a policy designed to enhance the experiences of students of diverse backgrounds.

As we analysed the data we collected, we used a curriculum commonplaces (Schwab, 1973) framework. We also thought narratively (Clandinin \& Connelly, 200o) about the stories lived on the school landscape as we considered the multiple perspectives related to this policy. We were mindful of the stories that called out in response to other stories (Chan, Ross, \& Keyes, 2012; Murphy, Ross, \& Huber, 2012) as we sought to make meaning of the experiences revealed through interactions with members of the school community. We kept in mind this re-emerging question-What narrative accounts need to be brought together and held in position beside one another in order for the many perspectives to be part of a whole?-as we engaged in the process of analysing experiences of this policy.

\section{The lens on the playground: policy in action}

Umar, a seventh grade middle school student, was at the centre of this examination of policy in action. Umar's physical assault on a peer, that caused 'bodily harm requiring treatment by a medical practitioner', (Minister of Education, 2000) was grounds for expulsion from his school, according to 'Bill 81' (Minister of Education, 2000).

Intertwined with this policy implementation was school practice, as implemented by teachers, administrators and other members of his school community. We present instances when policy met practice here in the form of fieldnotes, and then further analyse these fieldnotes in the following sections.

A policy meets practice-'The school administrator followed appropriate guidelines'

The girl's parents were called. His parents were not called. The police interviewed him for over an hour in the office and oops, right at recess time when all the kids were going out, they took him out in handcuffs so that the whole junior school out on recess saw him. (Fieldnotes, April 2002) 
The school-parent relations officer at the school told us about how the administrator called the police without first calling the 'perpetrator's' parents

A policy meets practice-'And the parents weren't informed.'

And the parents weren't informed that this was going to happen. The police told her (the administrator) that she was not to call the parents of that child until after they left the school property. (Fieldnotes, April 2002)

Policy in practice: the safe schools policy

While calling the police to report that a 12-year-old boy had punched a peer on the school ground may sound extreme, incidents such as the schoolyard fight have, in fact, been identified as among activities leading to suspension according to 'Bill 81' (Minister of Education, 2000). This bill, described as 'an Act to increase respect and responsibility, to set standards for safe learning and safe teaching in schools and to amend the Teaching Profession Act' (Minister of Education, 2000), guides the establishment and implementation of policies such as the Safe Schools Policy (Toronto District School Board, 1999) within the school board. More specifically, 'Bill 81' (Minister of Education, 2000) states that students who have engaged in any of the following activities may expect to be expelled:

(1) Possessing a weapon, including possessing a firearm.

(2) Using a weapon to cause or to threaten bodily harm to another person.

(3) Committing physical assault on another person that causes bodily harm requiring treatment by a medical practitioner.

(4) Committing sexual assault.

(5) Trafficking in weapons or in illegal drugs.

(6) Committing robbery.

(7) Giving alcohol to a minor.

(8) Engaging in another activity that, under a policy of the board, is one for which expulsion is mandatory (p. 8).

The Safe Schools Policy (Toronto District School Board, 1999), in turn, includes guidelines to support educators in the development of procedures for a safe school environment that is 
free of negative factors such as abuse, bullying, discrimination, intimidation, hateful words and deeds and physical violence in any form. (p. 1).

This set of guidelines, mandated by legislation, provides the backdrop for this exploration of experiences on the school landscape as a policy is implemented. We explore these guidelines in relation to existing research literature addressing issues of equity in diverse schools.

Building equitable and welcoming schools-examining existing literature

We recognize that there is currently a large body of literature highlighting the importance of welcoming the cultures and languages of immigrant and minority students in school contexts (Banks, 2007; Banks \& McGee Banks, 1995; Cummins, 2001; Igoa, 1995; Nieto \& Bode, 2011; Soto, 1997), and acknowledging the role of culturally responsive and culturally relevant curriculum (Gay, 2010; Ladson-Billings, 1995, 2001; Villegas, 1991) in building an equitable and welcoming school community. We embrace these ideas and the commitment to equity that they represent.

\section{Understanding policy at the macro-level}

Within the body of literature examining how educators might better serve students of minority background in school is a call for studies focusing on the implementation of policies and practices that enhance access of minority students to academic resources. Some of the research reveals ways in which existing policies and practices do not seem to achieve goals set by policy-makers to ensure equitable access of minority students to school services (Hamann \& Zu'n ${ }^{\sim}$ iga, 2011). Bruening's (2012) year-long study of the experiences of Latino students in a low-incidence (ESL student) Midwestern high school contributes to the growing but still limited body of literature examining ways in which students' experiences of school-based policies and practices intended to support ELLs are different than anticipated by policy-makers, teachers and administrators. In a recent article, Ross and Chan (2008) explore the 'particular' (Schwab, 1969) nature of student experiences, and ways in which the experiences of individual 
students, as shaped by circumstances unique to their own situations, may be overlooked in the context of a busy urban, middle school setting when the needs of so many need to be taken into consideration. A more in-depth examination of the experiences of individual students reveal a complex intersection of factors that contribute to shaping ways in which the students respond to curricular practices and schoolbased policies (Chan \& Ross, 2009). Realization of the potential of these factors to contribute to students' academic achievement and social growth reinforce the need for further knowledge about ways in which students and their parents may experience school policies designed to enhance equity of access to schooling and its benefits.

Skiba and Peterson (1999), in their examination of the 'dark side' of zero tolerance policies, uncover the potential for negative impact when the circumstances in some students' lives contribute to an increased likelihood of punishment for not abiding by school policies designed to build safer schools. In this work, Skiba and Peterson (1999) outline ways in which disciplinary measures in schools are becoming increasingly extreme in their implementation. Paradoxically, these measures do not necessarily create safer school communities, as intended (American Civil Liberties Union 2008, 2012).

Although policy implementation is more commonly recognized as the work of teachers and administrators who have been charged with putting policy into action, examination of the impact of this implementation on students has been curiously overlooked. Notably, even in the subfield of educational policy implementation studies which claim to be increasingly well established (Hamann \& Rosen, 2011; Honig, 2006; Levinson \& Sutton, 2001; McLaughlin, 1987), and even within a branch described as anthropological studies of educational policy implementation where policy is defined more broadly, distinctions between policy formation and implementation are blurred and problematized. Interpretation, rather than explanation and prediction, of policy continues to be the goal (Hamann \& Rosen, 2011), and the focus does not seem to be directed towards the examination of student experiences of policies.

Levinson and Sutton (2001) introduce their series examining policy as practice by stating that 'a deeply cultural approach to educational policy has yet to be developed' (p. 4), highlighting the extent to which there is a need for 'locally informed, comparatively astute, ethnographically rich accounts of how people make, interpret, and 
otherwise engage with the policy process' (p. 4). They (Levinson \& Sutton, 2001, p. 1) further argue that 'the growing focus on policy implementation ... has conferred legitimacy upon some constructs and approaches that draw more broadly from fields like anthropology and cultural studies' as a means of examining challenges of moving from policy to practice. Despite a previously quantitative history in examining educational policy, qualitative research methods have become more acceptable as a means of informing our understanding of the interconnections between cultural, contextual and political dimensions of educational policy.

\section{Reverberations of policy in the school community}

As the story of this policy's implementation unfolds, we are reminded of the extent to which it touches many in the school community. To begin with, the experience extends beyond the students at the centre of the altercation, and touches the administration. The story moves from the parental arena into the middle school student body. It is also felt in teaching ranks. In essence, this policy was lived by a school community. We present some of these voices here.

A contentious meeting: parents express concern

One parent who attended the School Council meeting stated, I don't care what the police said, because first of all, we know that children have been arrested before. It has never ever happened this way where a child is paraded in front of all of these kids. We also know that the (previous) administrator has handled it in a completely different way. This way seemed to have been set up to degrade a child. I think that you have scarred this child by the way in which it was handled. (Fieldnotes, April 2002)

While many parents voiced disagreement about how the administrator had handled the situation, the administrator's decision to suspend Umar was, in fact, in line with guidelines recommended for school administrators in the Safe Schools Policy (Toronto District School Board, 1999). More specifically, it is stated that: 
The Board does not tolerate any anti-social or violent behavior that impacts on learning environments. ... the Board provides a framework for dealing with violent incidents that includes due process in delivering a range of appropriate consequences for inappropriate behavior. (p. 3).

Furthermore, it is stated in 'Bill 212' (Minister of Education, 2007) that

310. (1) An [administrator] shall suspend a pupil if he or she believes that the pupil has engaged in any of the following activities while at school, at a school-related activity or in other circumstances where engaging in the activity will have an impact on the school climate

When parents at the school heard about what had happened, however, many were outraged that a child would have been questioned, and then taken to the police station in a cruiser, in handcuffs, no less, without his parents having been informed. They were angry about the lack of respect for the child whom they believe had been degraded by the procedure, and the lack of respect for the child's siblings whom witnessed their older brother being taken away at recess when most of the students were out on the school grounds. Most of all, they expressed outrage at the lack of respect for the child's parents, who they felt had a right to be informed of what was happening to their child.

\section{The classmates left behind}

In the days and weeks following the incident, other students in the school were also drawn into discussions about the incident. Some of these discussions are presented here, in the form of fieldnote records of conversations with the school-parent relations officer in the school.

Practice-'Behavior like this will not be tolerated!'

And then a couple of days later the administrator and the police officer who comes into the school all the time, Mike McCowan, had assemblies with the middle school kids. He (the police officer) was the first one there (when Umar had been taken in) and the child who was arrested (Umar) had 
been in trouble before for breaking school windows during the summer vacation, so he had dealt with him before. He pretty much said, 'Well, we are going to arrest him so we will get a couple of people to come over.' A couple of days later he and Jackie Steadman (a school administrator) had assemblies with the kids and said, 'Behavior like this will not be tolerated! This is what will happen to you if you do this'. (Fieldnotes, April, 2002)

Some believed the incident might have been presented as a learning opportunity, and as a way for students to learn about expectations and appropriate behaviour in school. The school-parent relations officer, however, believed the child had been targeted, and made an example of behaviour not to be accepted within the school.

\section{Putting the snapshot back into time}

We examine next the perspectives of some members of the school community, to explore in further detail ways in which these interactions contributed to difficulties in coming to a consensus about appropriate practices and policies to support their diverse student population.

The student: Umar at the centre of the commotion

The school-parent relations officer who recounted the schoolyard fight to us insisted that the schoolyard fight was not racially based, and that the word 'race' was never mentioned. The incident, nevertheless, developed into a racial issue as parents, teachers and administrators in the school referred to the School Council Meeting where the incident was so hotly discussed because the student at the centre of this incident-Umar-was a Black student.

Umar was in the seventh grade when the schoolyard incident took place. From our perspective, as researchers, Umar was seemingly quiet and unobtrusive, though in fact, Umar was well known among teachers, administrators, parents and students alike. His teachers knew him because he had a long history of incidences ranging from a lack of focus in academic pursuits to truancy and inappropriate classroom behaviour stretching back as far as his time in the school. Although we 
rarely had direct interaction with Umar because he was in the other seventh grade homeroom and was often absent from school, his name often came up in conversations among his classmates as they shared accounts of his inappropriate behaviours with them.

The schoolyard fight was another example of Umar's inappropriate behaviour in school. While the intensity of the issues became more apparent to us after they initially surfaced at the School Council meeting, Umar's reputation within the school community seemed to fuel ongoing talk among the students. Meanwhile, parents, teachers, school staff and administrators were caught up in much discussion and reflection about what the fight meant in this culturally diverse school.

The teachers, the parents: tense interactions among members of the school community

Issues of race also surfaced in interactions between Umar's teacher, William, and a black parent at the School Council meeting. William believed that Umar had misbehaved and that the parents, who were voicing disagreement about the way in which the incident had been handled by the administrator, were overlooking the fact that the student had not behaved according to school rules. Furthermore, William believed that the administrator had acted appropriately, according to guidelines outlined in the Safe Schools Policy (Toronto District School Board, 1999) and in 'Bill 81' (Minister of Education, 2000), and that parents who voiced their disagreement about the way in which the incident had been handled were doing so in an inappropriate manner. He expressed his belief that parents who had spoken inappropriately should be banned from future participation in the School Council.

Parents, in turn, disagreed, and felt that it was their right to express their ideas and interpretations about the student and about how he had been disciplined. In the weeks following the School Council meeting, as members of the school community reflected upon and further discussed the incident and interactions among those present at the School Council meeting, William expressed frustration that he was being perceived as racist when he disagreed with the views of a Black parent about how Umar had been disciplined. As a male of European background, he expressed concern that he would be perceived as representing a privileged position if his views differed from those of parents of minority background. Reflection upon the incident lead us to 
wonder whether William's positive attitude towards diversity and his willingness to learn about the languages and cultures of his students were sufficient, when despite his seemingly supportive beliefs and practices, parents of ethnic minority backgrounds might nonetheless perceive racist tendencies when he revealed a perspective different from what they expressed (Chan, 2006).

The student, the parents: voices overlooked

Stories of Umar, as told and retold by his peers, teachers, administrators, parents and other members of the school community, intersected to reveal multiple perspectives about an individual student that needed to be considered in learning to meet his academic and social needs. The details of the stories create a layered body of knowledge to inform the work of his teachers as they develop and implement school curriculum for him. The details also highlight challenges his teachers may face as they deliberate the layers of meanings to develop and implement curriculum to meet his academic and social needs at school.

One such layer is expressed by parent members of the School Council. These members of the school community spoke with conviction about the importance of acknowledging diversity as an asset within the school. This mindset is in accordance with school board equity policies stating that

The Toronto District School Board values the contribution of all members of our diverse community of students, staff, parents and community groups to our mission and goals. We believe that equity of opportunity and equity of access to our programs, services and resources are critical to the achievement of successful outcomes for all those whom we serve, and for those who serve our school system.

The Board further recognizes that such inequitable treatment leads to educational, social and career outcomes that do not accurately reflect the abilities, experiences and contributions of our students, our employees, and our parent and community partners. This inequitable treatment limits their future success and prevents them from making a full contribution to society. (Toronto District School Board, 1999) 
These policies are embedded within a societal context that is supportive of diversity. For example, it is stated in the 'Canadian Multiculturalism Act' (Minister of State, 1988) that,

... the Government of Canada recognizes the diversity of Canadians as regards race, national or ethnic origin, colour and religion as a fundamental characteristic of Canadian society and is committed to a policy of multiculturalism designed to preserve and enhance the multicultural heritage of Canadians in the economic, social, cultural and political life of Canada. (Minister of State, 1988)

For many of the Black parents at Bay Street School, active participation in groups such as the School Council was critical to the maintenance of programmes to support Black culture and language for their children in school (Chan \& Ross, 2009). This incident further reinforced their belief in the importance of active participation and voice within the school community.

As we reflected upon the incident, the existence of missing voices also emerged. We have an idea of the perspectives of the parents who were actively involved in the School Council, and who expressed loudly their outrage that the parents of the student being disciplined for his participation in the schoolyard fight had not been contacted before the police had been called. The importance of recognizing these parents' voices is not easily overlooked, but we wondered about the voices of other parents who did not participate in the School Council meetings or those who did not feel that they could offer their perspectives amid the tensions once the voices of those who had been most vocal had been expressed.

More specifically, we wondered about Umar's parents. We had initially assumed that Umar's parents were among those who had voiced outrage. When we later asked the school-parent relations officer about Umar's parents, we were told that his mother had decided to approach the incident spiritually, and to address this difficult situation involving her son by attending Bible study groups more frequently. She had not attended the School Council meeting nor had she expressed her preferences about how the incident should have been handled in the school. We wondered about events leading up to this point, and how she approached her participation in her son's school 
community. Did she feel welcome to attend meetings and to talk with her child's teachers? Did she feel she could disagree or offer her own perspectives when they differed from those of teachers, administrators and other parents who were more vocal? What dreams did she have for her child, and how had his participation in school thus far contributed to the shaping of these dreams? There were many questions we would have liked to have spoken about with Umar's mother, but it was only in hindsight that we realized this missing voice. Did teachers, administrators and others members of the school community wonder about Umar's mother's perspectives as they were so passionately expressing their own perspectives? Did they ask Umar's mother about these perspectives?

We realize our portrayal is incomplete but also recognize that this oversight is not uncommon when disagreements develop and are expressed-some perspectives come across loudly while others may not be heard or acknowledged. We wondered how this uneven portrayal contributed to the development and implementation of practices and policies in this community in particular and in school communities in general. We thought about how it might be informative to view different, and sometimes conflicting, perspectives as recognition of the complexities of specific situations and contexts. Varying perspectives could be seen as contributing to a deeper understanding of the overall difficulty of coming to an 'effective' policy for a particular context, rather than as obstacles to coming to a consensus about effective policies and practices to address behaviour deemed undesirable in a school.

This study is informed by Dewey's (1938) philosophy of the interconnectedness between education and experience in relation to specific students' and teachers' experience of the extent to which a particular policy is supportive of student academic achievement and social growth. In particular, we question the extent to which policies guiding safe school practices support the academic achievement goals and social development of students at risk. We acknowledge Connelly and Clandinin's (1999) notion of professional knowledge landscapes, such as schools, as moral spaces that are narratively structured, and highlight the importance of attending to the people, context and circumstances shaping the schoolyard incident. Drawing upon Schwab's (1969/1978) curricular lens of the 'particular', we explore complexities that members of the school community encountered in 
the implementation of practices and policies to support their diverse student population. Ultimately, and more specifically, we explore what stories about students, as told and retold from multiple perspectives, teach us about challenges minority students may encounter. We examine ways in which the move toward implementing well-intended practices and equity policies may reveal complexities that members of the school community may not have anticipated initially. We highlight the extent to which this body of teacher knowledge about specific students focuses on the 'particular' (Schwab, 1969/1978) circumstances of individual students, and is fundamentally deliberative (Schwab, 1983). Schwab's (1959/1978) notion of the 'pragmatic intellectual space' (p. 174) is presented as a space where teachers and teacher educators might deliberate stories of experience about students, such as the one described here, as a resource for building a body of teacher knowledge.

\section{Looking beyond the borders: wonders emerging from this experience}

Our interest in school equity policies and practices was piqued as we observed the passion with which members of the School Council discussed a schoolyard incident. Ongoing, in situ examinations by members of the school community of the policies and practices guided by 'Bill 81' (Minister of Education, 2000) were revealing. While general agreement emerged that Umar had many difficulties adapting to his school context, these examinations of the responses of members of the school community highlighted the complexity of the situation, and challenges of implementing practices and policies to meet the needs of a diverse student population.

We wondered about the root of the tensions expressed by parents, teachers and administrators in attendance at the School Council meeting. As we learned more about the schoolyard incident, the student at the centre of this incident, and about the practices and policies in place to support the maintenance of a 'safe school', we began to consider the extent to which the implementation of school and school board practices and policies were appropriate or adequate in engaging a student like Umar, who had many challenges within, as well as beyond his school context. Given that punishment for Umar's involvement in the 
schoolyard fight likely contributed to further alienation from school, peers and teachers, we questioned whether the experience might have been more miseducative than educative (Dewey, 1938) for him.

The incident illustrates how policy-makers, in attempting to resolve the pernicious problem of student safety and parent participation through provincial legislation of policies may, in some cases, contribute to limited options for administrators and teachers to respond to the unique needs of individual students. It seems apparent in this context that existing school practices and policies were not sufficient in meeting Umar's needs or the needs of the parents who protested to the way in which he had been disciplined. These issues, in fact, bring to light an even more complicated and layered understanding of associated challenges. The administrator, in her response to the schoolyard fight, was abiding by guidelines outlined in Bill 212 where it is stated that, '[administrators] must suspend students who ... commit a physical assault' (Minister of Education, 2007). Elsewhere, Chan and Ross (2009) examine the extent to which existing school policies may not be sufficient in meeting the needs of particular students since they cannot account for the unique circumstances of specific situations as they arise. The complexities associated with this incident might be understood in terms of a rift between theory and practice (Schwab, 1969/1978). Schwab (1969/1978) argues that theory, taken on its own, is inadequate as a means of solving real problems involving real individuals - the practical matters with which members of a school community must wrestle. We believe that policy in this situation was used in a pointedly theoretical way. Schwab (1969/1978) asserted that policy is a 'summary of the past effective deliberations of the institution whose policy it is' (p. 290). Parents' voices seemed to convey a sense of discord surrounding how incidents involving the police were handled within the school community. Policy seemed to be more ideologically driven and theoretically utilized rather than addressed with a more deliberative stance, in this situation.

A deliberative stance, on the other hand, encourages a more nuanced understanding of the role of teaching, and schools, in the larger picture of society. While it would be desirable to have answers about how best to address difficult issues such as school safety and parent participation with the provision of practices guided by fool proof policies, the nature of schooling is highly complex and often does not lend 
itself to straightforward solutions. Such an appreciation of the nature of schooling is foundational to understanding the development of a 'pragmatic intellectual space' (Schwab, 1959/1978).

\section{Marking this picture and turning the page}

In this discussion, we balance between exploring the complexities revealed through this story while at the same time looking to a way of shifting our understanding to a more hopeful frame. To do so, we first affirm our belief in the professional knowledge landscape of teachers (Clandinin \& Connelly, 1995) as moral spaces that are narratively constructed by attending to the people, context and circumstances shaping the implementation of educational equity practices and policies. We recognize the potential for these narratively structured, moral contexts of teaching as intellectual spaces where knowledge about students may be gathered through interaction with others on the school landscape. It is within this space where storying and restorying occur that the possibilities arising from reconstruction of experience (Dewey, 1938) emerge. In this article, we catch glimpses of ways in which the Bay Street School landscape could be considered such an intellectual space for Umar's teachers. Varying perspectives of teachers, parents, administrators and students involved in the incident contributed to a body of knowledge where multiple perspectives held by members of the school community, including the 'second-hand stitched together stories' (Clandinin et al., 2006) of the student lives pieced together through long-term participation on the school landscape, form a body of professional knowledge from which appropriate practices may be developed and implemented.

The multiple perspectives-the many stories-of Umar at Bay Street School, as told by his peers, teachers, administrators and parents, intersect to tell a story of a minority student not positively engaged in his academic growth in the school community due to competing family and community influences that impact upon his ability to focus on school work. This was also the case with a number of students whose experiences were featured in other diverse school contexts (Chan \& Ross, 2009; Ross \& Chan, 2008; Schlein \& Chan, 2010). These stories, in turn, may inform the work of beginning and practicing teachers as they build a body of teacher knowledge that continues to grow 
through their careers. It is in this space of intersecting stories that teachers may piece together stories of students, and work through the puzzles of these students and their lives. This reflection and deliberation opens the possibility for a 'pragmatic intellectual space' (Schwab, 1959/1978, p. 174).

Schwab (1959/1978) spoke of the pragmatic intellectual space as a place where the teacher must also be a learner, and constantly maintain a balance in their role as both learner and teacher. We suggest this idea of a 'pragmatic intellectual space' as a framework for teachers working in diverse school communities to grow their body of knowledge about students and school landscapes. The implementation and growth of this space would provide a structure for professional development where deliberation about the curricular needs of students of diverse backgrounds is encouraged among members of the school community, and where implications and nuances are deliberated, considered and reconsidered. Levinson and Sutton (2001) acknowledged that the process of conducting research has the potential to put researchers in a position of opening up channels of communication among participants in different moments of policy formation, and that the presence of researchers sometimes creates new and different venues for communication about policies among parents, students, teachers and educational authorities. This notion from Schwab's (1959/1978) work is also echoed in Craig and Ross' (2008) work exploring and furthering Clandinin and Connelly's (1992) metaphor of the teacher as curriculum maker. We take this idea a step further to advocate for the space for extensive discussion about school-based incidents among members of the school community as a means of acknowledging complexities of teaching (Cochran-Smith, 2003; Lampert, 1985; Schwab, 1959/1978), and as a resource for professional development for teachers and administrators.

We encourage the development of this body of teacher knowledge about the experiences of immigrant and minority students, and we argue that this knowledge needs to be based on multiple perspectives that include space for students' telling of their own stories. Kerby (1991) writes about the notion of being storied by others, and refers to how in many ways, our stories of ourselves are written before we ever have a chance to construct them ourselves. As we considered this notion of a space in which to puzzle through details of student lives and student experiences of school practices and policies, we also 
bumped up against a sense of emptiness. We had knowledge of Umar from the stories others told about him, but what were his stories of himself? And possibly more importantly, what kinds of stories would he present of himself in relation to those told by others? Do the stories change and shift over time and in relationship with different people and different situations? In this school where so much consideration was made for the inclusion and implementation of equitable practices and policies, had we overlooked the importance of providing students with an outlet for telling stories of themselves, and acknowledging these stories as essential knowledge to be considered in the development of appropriate curriculum and practices? Referring back to our purposes for this paper, we realized the importance of including ways for students' autobiographical stories to be included among those told by others. We offer the idea of the pragmatic intellectual space as a place where individual's stories of oneself are considered alongside those told by others.

By applying this notion of the pragmatic intellectual space to the contexts of teacher practice, other aspects pertaining to the idea of teacher knowledge emerge. When the idea of an intellectual space is associated with aspects of intellectual work among teachers within their professional communities, then it might be appropriate to suggest that the development of teacher knowledge may be redefined in important ways. For example, this perspective may reinforce teacher knowledge as a body of knowledge that is shaped by teaching and learning experiences and acknowledged by administrators, educational researchers and society as a whole. Furthermore, this perspective redefines the role of education researchers such that it may be more in keeping with Schwab's (1983) vision for the curriculum specialist. Teachers are necessarily caught up in the 'particular' (Schwab, 1969) nature of their work in that they deal with particular children, in particular situations, and about the teaching of particular lessons to those students. We hear echoes of this in William's account of the schoolyard incident. If teachers are caught in the web of the particular, so too are parents as they guide their children through their academic and, indeed, life paths. Even school administrators are caught in the web; theirs, though, is a concern for their particular school as they enact and implement policies to bring into existence a vision of their school. The professor of curriculum, however, has the luxury of being able to examine, perceive and interpret situations from afar; not 
tied to the particular, the curriculum professor may take into account the multiple, and at times conflicting, understandings of the particular that teachers, parents and administrators carry as constituent of the body of knowledge.

Teachers creating a pragmatic intellectual space, through the gathering, construction and reconstruction of stories of students and students' stories, hint at the important place of the act of deliberation. While teachers are necessarily caught in the particular practice at the heart of education, the process of deliberation brings these particulars together, further contributing to a context for understanding nuances. The schoolparent relations officer featured in this piece, in her work of establishing parent community (re)presentation in the school, facilitated a coming together of 'divisions of human thought and interest' (Schwab, 1959/1978, p. 174) that would be conducive to the building of a pragmatic intellectual space.

Teacher education, in turn, exists in a space of tension between the professional obligations we have for our education students, as well as the children they are preparing to teach. As we support their professional growth in this professional knowledge landscape, we believe that understanding the intersecting contexts of practice as an intellectual space shaped by influences including those from outside the school landscape is a valuable perspective from which our pre-service teacher candidates might begin.

\section{Educational significance}

Examination of issues arising from this incident contributes to reallife understanding of Multicultural Education from the perspective of teachers, administrators, parents and students in a diverse school community. Reflection upon the responses of members of the school community following the schoolyard fight and discussions at the School Council meeting highlighted the extent to which being culturally sensitive in supporting the students meant something different for each of the individuals involved. Teacher, parent, administrator and student perspectives of the way in which school and school board policies developed in accordance with 'Bill 81' (Minister of Education, 2000) emphasize the importance of acknowledging differences but also reveal challenges inherent to coming to a consensus 
about how policies are to be implemented when such vastly different perspectives need to be taken into consideration.

Notable in this research is the potential of a narrative inquiry approach to highlight multiple perspectives surrounding events such as a schoolyard fight. Acknowledging the multiple perspectives that become apparent in the storying and restorying process highlighted the deliberative role of teaching and learning, and provided a model for building a body of professional knowledge for beginning and practicing teachers.

This work contributes to the growing body of narrative inquiry research acknowledging the nuances and complexities of the lived experiences of educational policy on school landscapes in transition (Bruening, 2012; Chan \& Ross 2009; Craig 2009). These studies, grounded in Jackson's (1968) tradition of long-term, in-depth analysis of practices, reveal nuances in the work of teachers as curriculum makers (Clandinin \& Connelly, 1992; Craig \& Ross, 2008), and highlight ways in which educational reforms that seem on the surface to be beneficial and supportive of student learning may in fact be experienced in troubling ways by the teachers and students involved (Craig, 2009). In this way, this study is example of the idea of 'multicultural education in action' (Schlein \& Chan, 2010), and offers further support for Craig's (2009) analysis of how a breakdown in the approach to accountability might occur not only between theory and practice but also between theory, practice and policy.

Funding - This work was supported by the Social Sciences and Humanities Research Council (SSHRC) of Canada [Grant number 410-2003-0573]; [Grant number 853-2004-0056] held by F. Michael Connelly and D. Jean Clandinin [Grant number 756-2005-0566] held by Elaine Chan.

\section{References}

American Civil Liberties Union. (2008). Locating the school-to-prison pipeline. Retrieved December 9, 2012, from http://www.aclu.org/files/images/asset_upload_fileg66_35553.pdf

American Civil Liberties Union. (2012). School-to-prison pipeline. Retrieved November 28, 2012, from http://www.aclu.org/racial-justice/ school-prison-pipeline 
Banks, J. A. (2007). Educating citizens in a multicultural society (2nd ed.). New York, NY: Teachers College Press.

Banks, J. A., \& McGee Banks, C. A. (1995). Multicultural education: Its effects on students' racial and gender role attitudes. In J. A. Banks \& C. A. McGee Banks (Eds.), Handbook of research on multicultural education (pp. 617-627). Toronto: Prentice Hall International.

Bruening, E. L. (2012). Latino English language learners' experiences at a low-incidence high school (Unpublished doctoral dissertation). University of NebraskaLincoln, Lincoln.

Chan, E. (2006). Teacher experiences of culture in the curriculum. Journal of Curriculum Studies, 38, 161-176.

Chan, E., \& Ross, V. (2009). Examining teachers' knowledge on a landscape of theory, practice, and policy. Curriculum and Teaching Dialogue, 11, 159-171.

Chan, E., Ross, V., \& Keyes, D. (2012). Narrative inquirers in the midst of meaningmaking: Interpretive acts of teacher educators. Advances in research on teaching, (Vol. 16). Bingley: Emerald Group Publishing Limited.

Clandinin, D. J., \& Connelly, F. M. (1992). Teacher as curriculum maker. In P. W. Jackson (Ed.), Handbook of research on curriculum (pp. 363-401). New York, NY: Macmillan.

Clandinin, D. J., \& Connelly, F. M. (1994). Personal experience methods. In N. K. Denzin \& Y. S. Lincoln (Eds.), Handbook of qualitative research in the social sciences (pp. 413-427). Thousand Oaks, CA: Sage.

Clandinin, D. J., \& Connelly, F. M. (1995). Teachers' professional knowledge landscapes. New York, NY: Teachers College Press, Columbia.

Clandinin, D. J., \& Connelly, F. M. (2000). Narrative inquiry: Experience and story in qualitative research. San Francisco, CA: Jossey-Bass.

Clandinin, D. J., Huber, J., Huber, M., Murphy, M. S., Murray Orr, A., Pearce, M., \& Steeves, P. (2006). Composing diverse identities: Narrative inquiries into the interwoven lives of children and teachers. New York, NY: Routledge, Taylor and Francis Group.

Cochran-Smith, M. (2003). The unforgiving complexity of teaching: Avoiding simplicity in an age of accountability. Journal of Teacher Education, 54, 3-5.

Connelly, F. M., \& Clandinin, D. J. (1988). Teachers as curriculum planners: Narratives of experience. New York, NY: Teachers College Press, Columbia.

Connelly, F. M., \& Clandinin, D. J. (1999). Shaping a professional identity: Stories of educational practice. London, Ontario: The Althouse Press; Faculty of Education, The University of Western Ontario.

Craig, C. J. (2009). The contested classroom space: A decade of lived educational policy in Texas schools. American Educational Research Journal, 46, 1034-1059.

Craig, C. J., \& Ross, V. (2008). Cultivating the image of teachers as curriculum makers. In F. M. Connelly, M. F. He, \& J. Phillion (Eds.), Handbook of curriculum and instruction (pp. 282-305). Thousand Oaks, CA: Sage.

Cummins, J. (2001). Negotiating identities: Education for empowerment in a diverse society (2nd ed.). Los Angeles, CA: California Association for Bilingual Education. 
Dewey, J. (1938). Experience and education. New York, NY: Simon and Schuster.

Gay, G. (2010). Culturally responsive teaching: Theory, research, and practice. New York, NY: Teachers College Press.

Hamann, E. T., \& Rosen, L. (2011). What makes the anthropology of educational policy implementation 'anthropological'? In B. A. U. Levinson, \& M. Pollock (Eds.), A companion to the anthropology of education (pp. 462-477). West Sussex: Blackwell.

Hamann, E. T., \& Zu'n $\sim$ iga, V. (2011). Schooling and the everyday ruptures transnational children encounter in the United States and Mexico. In C. Coe, R. Reynolds, D. Boehm, J. M. Hess, \& H. Rae-Espinoza (Eds.), Everyday ruptures: Children and migration in global perspective (pp. 141-160). Nashville, TN: Vanderbilt University Press.

Honig, M. (2006). New directions in education policy implementation. Albany, NY: State University of New York Press.

Igoa, C. (1995). The inner world of the immigrant child. New York, NY: St. Martin's Press.

Jackson, P. W. (1968). Life in classrooms. New York, NY: Teachers College Press.

Kerby, A. P. (1991). Narrative and the self. Bloomington, IN: Indiana University Press.

Ladson-Billings, G. (1995). Multicultural teacher education: Research, practice, and policy. In J. A. Banks \& C. A. McGee Banks (Eds.), Handbook of research on multicultural education (pp. 747-759). Toronto: Prentice Hall International.

Ladson-Billings, G. (2001). Crossing over to Canaan: The journey of new teachers in diverse classrooms. San Francisco, CA: Jossey-Bass.

Lampert, M. (1985). How do teachers manage to teach? Perspectives on problems in practice. Harvard Educational Review, 55, 178-194.

Levinson, B. A. U., \& Sutton, M. (2001). Introduction: Policy as/in practice - A sociocultural approach to the study of educational policy. In M. Sutton \& B. A. U. Levinson (Eds.), Policy as practice: Toward a comparative sociocultural analysis of educational policy (pp. 1-22). Westport, CT: Ablex.

Maxwell, J. A. (1992). Understanding and validity in qualitative research. Harvard Educational Review, 62, 279-300.

McLaughlin, M. (1987). Learning from experience. Lessons from policy implementation. Educational Evaluation and Policy Analysis, 9, 171-178.

Minister of Education. (2000). Bill 81: An Act to increase respect and responsibility, to set standards for safe learning and safe teaching in schools and to amend the Teaching Profession Act. Ontario: Legislative Assembly of Ontario. Retrieved October 10, 2012, from http://www.ontla.on.ca/bills/bills-files/37_Parliament/Session1/bo81ra.pdf

Minister of Education. (2007). Bill 212: An act to amend the Education Act in respect of behavior, discipline and safety. Ontario: Legislative Assembly of Ontario.

Minister of State (Multiculturalism). (1988). Canadian Multiculturalism Act. Retrieved November 4, 2004, from http://www.pch.gc.ca/progs/multi/policy/ act e.cfm 
Ministry of Education and Training. (2004a). About the OPC: History and role of the OPC. Retrieved September 14, 2004, from http://www.ontarioparentcouncil.org/about the opc/default.asp?load=contributions1

Ministry of Education and Training, Ontario. (2004b). School Councils. Retrieved September 14, 2004, from http://www.ontarioparentcouncil.org/school councils $/$ Default.asp? language $=$ English

Murphy, M. S., Ross, V., \& Huber, J. (2012). Attending to the temporal dimension of narrative inquiry into teacher educator identities. In E. Chan, V. Ross, \& D. Keyes, Narrative inquirers in the midst of meaning-making: Interpretive acts of teacher educators. Advances in research on teaching (Vol. 16, pp. 51-75). Bingley: Emerald Group.

Nieto, S., \& Bode, P. (2011). Affirming diversity: The sociopolitical context of multicultural education (6th ed.). New York, NY: Longman.

Pipher, M. (2002). The middle of everywhere: Helping refugees enter the American community. New York, NY: Harcourt.

Ross, V., \& Chan, E. (2008). Multicultural education: Raj's story using a curricular conceptual lens of the particular. Teaching and Teacher Education, 24, 1705-1716.

Schlein, C., \& Chan, E. (2010). Supporting Muslim students in secular public schools. Diaspora, Indigenous, and Minority Education, 4, 253-267.

Schwab, J. J. (1959/1978). Chapter 6: The 'impossible' role of the teacher in progressive education. In I. Westbury \& N. J. Wilkof (Eds.), Science, curriculum, and liberal education: Selected essays (pp. 167-183). Chicago, IL: University of Chicago Press.

Schwab, J. J. (1969/1978). Chapter 10: The practical: A language for curriculum. In I. Westbury \& N. J. Wilkof (Eds.), Science, curriculum, and liberal education: Selected essays (pp. 287-321). Chicago, IL: University of Chicago Press.

Schwab, J. J. (1973). The practical 3: Translation into curriculum. The School Review, 81, 501-522.

Schwab, J. J. (1983). The practical 4: Something for curriculum professors to do. Curriculum Inquiry, 13, 239-265.

Skiba, R., \& Peterson, R. (1999). The dark side of zero tolerance: Can punishment lead to safe schools? The Phi Delta Kappan, 80, 372-376, 381-382.

Soto, L. D. (1997). Language, culture, and power: Bilingual families and the struggle for quality education. Albany, NY: State University of New York Press.

Statistics Canada. (2007a). 2006 Census: Immigration, citizenship, language, mobility and migration. Retrieved July 12, 2008, from http://www.statcan.ca/ Daily/English/071204/do71204a.htm

Statistics Canada. (2007b). Immigration in Canada: A portrait of the foreign-born population, 2006 Census. Retrieved June 1, 2008, from http://www12.statcan. ca./english/census06/analysis/immcit/pdf/97-557-XIE2006001.pdf

Statistics Canada. (2008). Canada's ethnocultural mosaic, 2006 Census. Retrieved July 1, 2008, from http://www12.statcan.ca/english/censuso6/analysis/ethnicorigin/pdf/97-562-XIE2006001.pdf 
Toronto District School Board. (1999). Equity Foundation Statement. Retrieved November 17, 2005, from http://www.tdsb.on.ca/ site/ViewItem.asp? siteid=1 $5 \&$ menuid $=684$ \&pageid $=548$

Toronto District School Board. (adopted 1999, revised 2000, 2005). Policy P. 051 SCH: Safe Schools Statement. Retrieved November 18, 2012, from http://www. tdsb.on.ca/ppf/uploads/files/live/98/220.pdf

U.S. Census Bureau. (2010). 2010 Census shows America's diversity. Retrieved June 21, 2012, from http://2010.census.gov/news/releases/operations/cb11cn125.html

Villegas, A. M. (1991). Culturally responsive pedagogy for the 1990's and beyond. Princeton, NY: Educational Testing Service. 